Gelanggang Olahraga: Jurnal Pendidikan Jasmani dan Olahraga

Volume 2, Nomor 1, Juli-Desember 2018

e-ISSN : 2597-6567

p-ISSN : 2614-607X

DOI : https://doi.org/10.31539/jpjo.v2i1.434

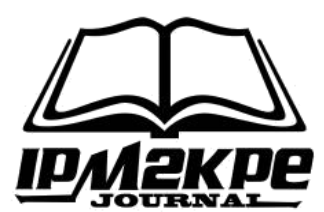

\title{
KEMAJUAN ALIRAN PENCAK SILAT TRADISIONAL BAKTI JANG PAT PETULAI DAERAH TUNGGANG ULAU DUES
}

\author{
Helvi Darsi ${ }^{1}$, Muhammad Supriyadi ${ }^{2}$ \\ Dosen STKIP-PGRI lubuklinggau ${ }^{1,2}$ \\ dr.helvidarsi.m.pd@gmail.com ${ }^{1}$
}

\begin{abstract}
ABSTRAK
Penelitian ini bertujuan untuk menelaah aliran Pencak Silat Tradisional Bakti. Jenis penelitian ini adalah Kualitatif, data diambil melalui observasi dan wawancara dengan menggunakan tekhnik bola salju melalui informan kunci yaitu seorang Tua Silat Bakti, dari informan itu di kembangkan informan lainnya sehingga terpenuhi semua data yang dibutuhkan, kemudian dianalisis menggunakan kata yang bisa disusun dalam teks yang diperluas atau melakukan analisis dari data yang diambil dari lapangan dan selanjutnya dideskripsikan dalam bentuk narasi. Hasil penelitian, pencak silat tradisional bakti ini berasal dari kata berbakti yang pertama mengembangkannya adalah nenek monyang, Pencak Silat Ini berkembang dengan pesat pada tahun 1965 s/d 1990, dan masyarakat Tunggang mulai kurang mempelajari Pencak Silat Tradisional Bakti Jang Pat Petulai sejak tahun 1987. Simpulan, bentuk pokok gerakan Pencak Silat ini akan terlihat pada kecepatan serta ketepatan elakan dan serangan pedang (pedang), elakan dan serangan piseu (pisau), serta ketepatan dan serangan dengan tangen kosong (tangan kosong).
\end{abstract}

Kata Kunci: Pencak Silat Tradisional, Jang Pat Petulai

\section{ABSTRACT}

This study aimed to examine Traditional Bakti martial arts flow. This type of research was qualitative, the data were taken through observation and interviews using snowball techniques through key informant namely Tua Silat Bakti, other informants were expanded from that informant so that all the data needed was completed, then the data was analyzed by using words which could be arranged in expanded text or did an analysis of data taken from the field and then it was described in narrative form. The results of this study, traditional bakti martial art came from the word filial*(berbakti)* which first developed by the ancestors, this martial art was developed rapidly in 1965 to 1990, and the Tunggang community began learning less the Traditional Bakti jat Pat Petulai Pencak Silat since 1987. In conclusion, the main form of the martial art movement would be seen in the speed and attack accuracy and sword attack (sword), dodgery and piseu attack(knife), as well as accuracy and attack with empty hand.

Keywords: Traditional Pencak Silat, Jang Pat Petulai 


\section{PENDAHULUAN}

Pencak silat merupakan hal yang penting saat ini adalah melestarikan dan mengembangkan, kebudayaan tradisional menjadi kebudayaan bangsa yang mengkristal sampai ke puncak pembangunan bangsa Indonesia ke depan yang betul-betul berkepribadian dan berbudaya, sebagai suatu bangsa yang bergerak maju tanpa meninggalkan budaya-budaya asli. Terkait dengan pembangunan di bidang olahraga khususnya olahraga tradisional maka sudah pasti perkembangan olahraga tersebut tidak hanya tertuju pada perkembangan olahraga yang sering dipertandingkan secara nasional, tetapi juga mencangkup keseluruhan cabang olahraga yang ada di masyarakat yang masih tradisional, meskipun demikian olahraga tradisional juga layak untuk di tumbuh kembangkan pada masyarakat secara tradisional. Daerah Kabupaten Lebong terdapat berbagai aliran pencak silat yang sudah lama berkembang, salah satunya pencak silat tradisional bakti jang pat petulai daerah tunggang ulau dues. Pencak silat tradisional bakti berdasarkan informasi guru silat dan para pemuka masyarakat setempat dahuluya pencak silat tradisional bakti berkembang dengan baik di daerah jang pat petulai desa tunggang ulau dues.Hampir di seluruh pelosok desa berdiri sasaran pencak silat tradisional bakti, kebanyakan terdapat di ulau dues, tanah lapang (lapangan terbuka) di depan mushola, lapangan, depan rumah, dan di dalam rumah.

Berdasarkan hasil wawancara dengan salah seorang guru silat di Kabupaten Lebong, Pikal (5 Mei 2017) mengatakan bahwa "Pencak silat tradisional bakti sudah dikenal masyarakat Kabupaten Lebong sejak puluhan tahun yang lalu, Pencak Silat Tradisional Bakti ini merupakan kebudayaan turuntemurun dan berkembang di tengah masyarakat Tunggang Kabupaten Lebong dan masih dipertahankan ciri-ciri khas gerakan silat murni yang masih utuh dan belum dipengaruhi oleh jenis bela diri yang lain". Tua silat Jafar (6 Mei 2017) mengatakan bahwa "Dahulunya Pencak Silat Tradisional Bakti ini dilakukan oleh pemuda yang ada diTunggang, salah satu tempat perguruan yang besar adalah di ulau dues (salah satu daerah di Tunggang)".

Dari pendapat di atas dapat disimpulkan bahwa seharusnya pencak silat tradisional bakti ini tetap berkembang sebagaimana mestinya namun berdasarkan kenyataan yang dilihat sekarang, Pencak Silat Tradisional Bakti perkembangannya sangat kurang sekali, bahkan dari hari ke hari jumlah anggota yang mau belajar semakin sedikit. Berdasarkan informasi yang diperoleh dari guru silat dan tua silat menyatakan bahwa keadaan tersebut dipengaruhi oleh generasi muda sekarang lebih memilih olahraga yang berasal dari Negara-negara asing seperti : judo, taekwondo, karate dan jenis olahraga beladiri lainnya yang dinilainya lebih trend. Sedangkan pencak silat mereka anggap olahraga bela diri yang biasa-biasa saja yang tidak mengikuti perkembangan zaman.

Berdasarkan kenyataan yang dilihat pada saat sekarang ini, dikhawatirkan pencak silat tradisional bakti akan hilang karena perkembangannya yang semakin berkurang, maka perlu diadakan penelitian untuk inventarisasi pencak silat tradisional bakti agar dapat mengenali sejarah, metode dan gerakan yang dipertakahankan sehingga tidak menghilang begitu saja dan dapat dikembangkan sesuai tuntutan zaman, dengan adanya penelitian ini diharapkan pencak silat tradisional Bakti Kabupaten Lebong, agar dapat di kenal, di pelajari dan berkembang. 


\section{KAJIAN TEORI}

\section{Asal Usul Pencak Silat Tradisional}

Kata pencak silat merupakan gabungan dari dua kata yaitu pencak dan silat, kata pencak lazim di gunakan di daerah Jawa sedangkan silat lazim di gunakan di daerah Sumatera dan daerah lainnya. Di kawasan melayu dapat ditemukan beladiri pencak silat dengan mempergunakan istilah bermacam-macam seperti bersilat, goyang, cekak di semenanjung Malaysia dan Singapur dan thailand provinsi pattani. Di Indonesia sendiri istilah pencak silat baru mulai dipakai setelah berdirinya organisasi pencak silat (IPSI), sebelumnya di daerah Sumatra lebih dikenal dengan istilah silat, sedangkan di tanah jawa kebanyakan dikenal dengan istilah pencak saja.Pencak silat dalam perwujudannya pada masyarakat Indonesia, berperan dan berfungsi sebagai olahraga, seni, beladiri, dan sebagai sarana pembinaan mental spritual bangsa Indonesia. Peran dan fungsi ini telah membudaya dan berkembang sejalan dengan pembangunan masyarakat Indonesia (Tua silat)

Menurut penjelasan di atas, bahwa pencak silat tradisional merupakan gambaran bentuk gerak bela diri yang bertujuan membela diri dari bala dan malapetaka yang dapat mengancam keselamatan.Pencak silat tradisional merupakan jenis beladiri yang masih bersifat tradisional, belum terpengaruh oleh budaya asing dan membudaya secara turun-temurun di Indonesia.Pencak silat yang masih bersifat tradisional, ini ada yang dapat tampil didepan umum dan ada yang tidak, silat yang dapat di tampilkan ialah bunga-bunga silat yang berupa jenis permainan dari pencak silat yang menampilkan gerakan. Menurut Lubis (2016) bahwa: 'Pencak silat merupakan salah satu olahraga yang bersifat tradisional yang tumbuh dan berkembang di Indonesia. Pencak silat juga merupakan beladiri yang telah di budayakan dan di kembangkan oleh nenek moyang bangsa Indonesia dan tersebar di seluruh pelosok tanah air, bahkan berkembang ke manca negara'.

Berdasarkan pendapat di atas menjelaskan bahwa pencak silat merupakan salah satu jenis bela diri tradisional yang telah di budayakan dan di kembangkan oleh nenek moyang bangsa Indonesia.Pencak silat merupakan kebudayaan bangsa yang tumbuh dalam masyarakat daerah-daerah yang ada di negara Indonesia.Banyak orang berpendapat bahwa pencak silat merupakan sebuah pemahaman dan pengalaman yang perlu dibekali.

Sedangkan pada tahun 1980 Eddie M. Nalapraya dalam Lubis (2016) dimintak sebagai ketua harian pencak silat PBIPSI bersama Tjokropranolo menyatakan bahwa:Pencak silat bukan hanya harus berkembang di Indonesia tetapi juga di seluruh dunia. Pencak silat adalah hasil budaya manusia Indonesia untuk membela dan mempertahankan eksistensi (kemandirian) dan Itegritasnya terhadap lingkungan hidup dan alam sekitarnya untuk mencapai keselarasan hidup guna meningkatkan iman dan taqwa kepada Tuhan Yang Maha Esa (.

Berdasarkan kutipan diatas, bahwa pencak silat merupakan hasil karya manusia yang sangat bermanfaat bagi kehidupan, selain itu melalui pencak silat juga dapat meningkatkan silaturahmi dengan sesama manusia ataupun dengan tuhan yang maha esa, selain itu pencak silat juga memupuk rasa nasionalisme seebagai tanda pengabdian terhadap Negara.Pencak silat dalam perwujudan pada masyarakat Indonesia berperan dan berfungsi sebagai olah raga, seni, bela diri, dan sebagai sarana pembinaan mental spritual bangsa Indonesia.Peran dan fungsi 
ini telah membudaya dan berkembang sejalan dengan pembangunan masyarakat Indonesia.

Sementara di masyarakat Lebong masyarakat menyebutnya dengan sebutan besilek dan begitu pula dengan gerakan-gerakannya, karena sangat tergantung pada dimana pencak silat ini di ciptakan atau di kembangkan. Seperti halnya di Kabupaten Lebong, disini pencak silat diistilahkan dengan besilek, sedangkan gerakan yang menggunakan pedang disebut dengan istilah Gerok yang artinya bergerak main untuk menyerang dan adalah kualitatif, dimana data lazimnya menggunakan observasi, wawancara dan juga memungkinkan sumber lain seperti dokumentasi Pendapat ini didukung oleh Barlian (2016), yang mengatakan bahwa data dapat dikumpulkan dengan melakukan observasi, wawancara, dan dokumentasi. Penilitian ini dilaksanakan di Daerah Tunggang Ulau Dues Kabupaten Lebong dan penelitian ini dilaksanakan pada tahun 2018.

Sesuai dengan karateristiknya, penelitian kualitatif tidak mengenal konsep "keterwakilan" sampel/informan yang harus ditarik dari populasi.Artinya, penelitian kualitatif hanya mementingkan kelengkapan informasi yang di kumpulkan, bukan pada berapa banyak sampel/informan itu menghindar. Menurut hasil observasi sementara Pencak Silat Tradisional Bakti ini berasal asli daerah Tunggang dan telah berkembang didesa Tunggang sejak lama.Perkembangan pencak silat tradisional bakti ini pernah mencapai puncak, namun kemudian menurun seiring perkembangan zaman dan kemajuan tekhnologi.

\section{METODE PENELITIAN}

Menurut Sugiyono (2012) bahwa "yang menjadi kepedulian penelitian kualitatif adalah luas dan rentang informasi yang di perlukan sesuai dengan elemen-elemen/fokus masalah penelitian.Karenanya jumlah sampel akan bergerak mengikuti karakteristik elemen yang ditemukan di lapangan sehingga jumlah sampel tidak dapat ditentukan sebelumnya".

Berdasarkan maksud kutipan di atas, maka untuk mendapatkan data/informasi yang bersifat kualitatif, penentuan sampel/informan penelitian ini mengikuti teknik bola salju (snow ball sampling). Dengan teknik ini informan/sampel akan diketahui melalui informan kunci (key informants). Sugiyono (2012) mengemukakan: "Strategi dasar teknik informan kunci (key informants) dan melakukan interview terhadap mereka secara bertahap atau berproses dalam melakukan penelitian, dan kemudian diketahui informan lainnya". Informan kunci (key informants) dalam penelitian ini adalah seorang tua silat yang ada di Tunggang Ulau Dues Kabupaten Lebong. Dari informan itu akan dikembangkan informan lainnya sehingga terpenuhi semua data/informasi kualitatif yang dibutuhkan.

Analisis data diambil melalui wawancara dengan menggunakan tekhnik bola salju snow ball sampling) melalui imforman kunci yaitu seorang tua silat Bakti, dari tua silat ini akan diperoleh imformasi tentang pencak silat tradisional bakti dan orang yang akan menjadi informan berikutnya (orang yang mengetahui tentang pencak silat tradisional bakti), kemudian dari informan diperoleh lagi imformasi tentang pencak silat tradisional bakti serta orang yang akan menjadi imforman berikutnya, begitu seterusnya. Wawancara (pengambilan data) berakhir apabila imformasi yang diberikan imforman, sama dengan informan-informan sebelumnya. Data yang di peroleh sesuai dengan tujuan pertanyaan penelitian, 
yaitu melalui analisis deskriptif yang di gunakan untuk melihat, meninjau, mengamati, dan mengungkapkan apa adanya tentang aspek yang diteliti sebagaimana pendapat Barlian (2016) yang menyatakan bahwa "Analisis data kualitatif adalah menggunakan kata-kata yang bisa disusun dalam teks yang diperluas atau melakukan analisis dari data yang diambil dari lapangan dan selanjutnya dideskripsikan dalam bentuk narasi".

\section{HASIL PENELITIAN}

\section{Hasil Yang Dicapai Dalam Penelitian}

Dari hasil penelitian mengenai Pencak Silat Tradisional Bakti Jang Pat Petulai Daerah Tunggang Ulau Dues Kabupaten Lebong.Hasil penelitian ini berdasarkan temuan yang di peroleh dari observasi dan wawancara di lapangan, berupa sejarah/asal-usul pencak silat bakti, persyaratan belajar pencak silat tradisional bakti, dan bentuk gerakan pencak silat tradisional bakti.

Pencak silat tradisional bakti jang pat petulai daerahtunggang ulau dues kabupaten lebong, menurut salah salah satu pewaris pencak silat tradisional bakti, Jafar,menjelaskan bahwa pencak silat telah ada semenjak zaman Nabi dahulunya, Nabi Muhammad SAW juga berbekal pencak silat untuk menghadapi orang-orang yang memusuhinya dalam menyebarkan agama islam, pencak silat ini disebut Kandang Agama islam (pagar agama islam) hal ini dibuktikan dengan setiap memulai latihan di awali dengan berdo'a kepada Allah SWT agar apa yang dilakukan dalam latihan dapat di berkati Allah SWT dan pada saat muloi lakeak(mulai melangkah) serta semudo(mengakhiri), dimulai dengan bismillah hirrahma nirrahim(dengan menyebut nama allah yang maha pengasih lagi maha penyang) dan di akhiri dengan Alhamdulillah hirabbil alamin(segala puji bagi Allah, tuhan semesta alam).

Menurut informasi penyebaran pencak silat dipengaruhi oleh perkembangan masyarakat dan perkembangan kebudayaan, menurut sejarah kebudayaan rejang sangat dipengaruhi oleh kebudayaan-kebudayaan dari daerah sekitar rejang, supeak (bersumpah) di ulau dues Kabupaten Lebong merupakan jalinan persahabatan yang akrab antara masyarakat sekitar.

Menurut Jafar salah seorang guru pencak silat tradisional bakti, mengartikan pencak silat tradisional bakti ini merupakan perpaduan dari dua unsur yaitu mecok (pencak) dan silek(silat). Mecok (pencak) merupakan tarian rejang yang gerakannya menggunakan lakeak num (langkah enam) gerakan lakeak num (langkah enam) merupakan langkah harimau yang di jadikan dalam bentuk tarian piseu garpu (pisau garpu), sedangkan silek(silat) merupakan ilmu bela diri yang gunanya menjaga diri dari bahaya yang mengancam kapanpun dan dimanapun. Perpaduan dari kedua unsur ini menjadikan satu rangkap seni gerak mecok silek(pencak silat) bakti. Beliau juga menjelaskan bahwa orang yang menemukan mecok(pencak) dahulunya bersahabat dengan harimau dan karena itulah gerakan mecok (pencak) di ambil dari lakeak num (langkah enam) yang meniru langkah harimau.

Kemudian informan juga menyebutkan sisilah keturunan yang mengembangkan pencak silat tradisional bakti yang pertama yaitu Munai, ilmu silatnya diwariskan kepada Ninik, kemudian Ninik mewariskan ilmu silatnya kepadaTua, Tua mewariskan pencak silatnya kepada Bapok, kemudian bapok mewariskan pencak silatnya kepada anok cucunyo, orang yang terakhir menerima 
pencak silat ini adalah ninik tuwai (kakek tua), beliaulah satu-satunya keturunan terakhir yang bisa masa belajea kemudian membuka perguruan di dekat rumahnya. Beliau menurunkan tata cara masa belajea kepada anak anak buah yang telah Tamat (menamatkan) pencak silat tradisional bakti ini, sehingga setelah itu beberapa mantan anak anak buah beliau sudah bisa membuka perguruan silat baru di beberapa tempat di Tunggang.

Menurut informan secara keseluruhan Pencak Silat Tradisional Bakti berkembang dengan pesat pada tahun 1965 s/d 1990, karena pada saat itu penduduk Tunggang beranggapan bahwa setiap anak laki-laki haruslah pandai pencak silat untuk menjaga diri, disamping itu seringnya terjadi pertikaian antar daerah juga menjadi faktor penduduk mengharuskan anak muda untuk mempelajari Pencak Silat Tradisional Bakti, terlebih pengalaman pahit masuknya Belanda, Inggris, Fortugis dan Jepang ke bengkulu membuat para orang tua membekali anak-anak mereka dengan ilmu bela diri Pencak Silat Tradisional Bakti ini dan masyarakat Tunggang mulai kurang mempelajari Pencak Silat Tradisional Bakti sejak tahun 1987di karenakan kemajuan zaman.

Hingga sekarang pencak silat tradisional Bakti ini perkembangannya sangat minim sekali, menurut informan hal ini dipengaruhi oleh minat generasi muda yang sangat kurang terhadap pencak silat tradisional Bakti. Menurut informan ada beberapa faktor yang menyebabkan generasi muda kurang berminat untuk mempelajari pencak silat tradisional Bakti ini yaitu masuknya olahraga beladiri baru dan moderen seperti karate, taekwondo, judo, whusu dan olah raga beladiri lainnya, selain itu informan juga berpendapat kemajuan tekhnologi juga mempengaruhi pencak silat tradisional bakti kurang diminati oleh generasi muda.

Pada Pencak Silat Tradisional Bakti terdapat dua unsur yang berbeda dalam persyaratan namun merupakan satu rangkaian Pencak Silat Tradisional Bakti yaitu Mencok (pencak) dan Silek (silat), Menceak (pencak) merupakan permainan pedang sedangkan Silek (silat) merupakan permainan pisau dan tangan kosong.Dalam mempelajari pencak silat ini yang terlebih dahulu dipelajari adalah Silek (silat), setelah itu barulah Mecok (pencak), Persyaratannya pun terdapat sedikit perbedaan.

Dalam menerima anak buah (murid), tidak terdapat pembatasan bagi anak buah (murid) untuk mempelajari pencak silat tradisional Bakti ini, baik itu Mecok (pencak) ataupun Silek (silat).Anak buah (murid) dapat di terima dari seluruh lapisan masyarakat, tidak memandang ekonomi, suku, strata sosial, dan pendidikannya yang menjadi syarat utama dalam mempelajari pencak silat tradisional bakti ini adalah "Bersedia mengikuti segala aturan yang di tentukan oleh guru silat".

Sebelum anak buah (murid) memasuki Kakea Latihan (tempat latihan), seorang anak buah (murid) harus memenuhi persyaratan secara bertahap. Tahapan pertama yaitu anak buah (murid) menyatakan niatnya untuk mempelajari silat tradisional bakti ini kepada guru silat, keinginan untuk belajar ini benar-benar berasal dari hati nuraninya tampa adanya paksaan dari orang lain dan menyanggupi segala bentuk persyaratan yang nantinya di anjurkan oleh guru silat.

Tahapan yang ke dua yaitu anak buah (murid) harus memenuhi persyaratan yang merupakan ketetapan dalam belajar pencak silat tradisional bakti. Tahapan ini biasa disebut Masa Belajea, menurut Jafar salah seorang guru silat pencak silat bakti“maso belajea wajib kemeliak anggota do luyen belajea 
kileak pakei keracok iben lengkap (waktu mau belajar silat bakti wajib memperhatikan anak murid yang lain terlebih dahulu dan membawak siri lengkap, jika tidak di laksanakan urutan tersebut maka apa yang akan di pelajari sulit untuk didapat dan mudah hilang)".

Dalam masa belajea ada beberapa persyaratan yang harus di penuhi oleh calon anak buah, diantaranya: harus menyiapkan Caci duwai belas ribau (Uang Rp.12.000,-) untuk diberikan dengan penduduk sekitar, Mei kuning secukup ne (nasi kuning secukupnya) untuk member makan penunggu di tempat penelitian, Piseu gerpu (pisau khas rejang) senjaya pertama yang digunakan penduduk rejang, Kain putiak 2,5 meter (kain putih 2,5 meter)untuk Silek (silat) dan kain meleu 2,5 meter (kain hitam 2,5 meter) untuk Mecok (pencak). Karena manusia suatu saat akan meninggal duni maka dari itu harus menyiapkan kain puti sedangkan kain hitam untuk menghargai tua silatyang terdahulu, Belas 12 cubuk(beras 12 canting) untuk makan tua silat selama mengajarkan calon pesilat dalam jangka waktu tujuh hari,Monok meleu dikup (Ayam hitam satu ekor) untuk penunggu tempat penelitian, Benik mis 12 ngan (Lemang manis 12 batang) untuk disimpan karena tua silat saman dulu sering bertama selama sepuluh hari tidak pulang ke rumah maka dari itu benik sebagai bahan makanan yang awet, sebelum latihan harus memakan Iben desubang (sekapur sirih lengkap) supaya tua silat muda mengenal anak buahnya,

Semua persyaratan diatas di letakan dalam bokoa iben(bakul yang terbuat dari bambu) kecuali sekapur sirih yang berupa dawen iben 12 lembea (daun sirih 12 lembar), Gambial2 lembea (gambier 12 lembar), buak pinang desoa (pinang sebijik), opoa iben (kapur sirih) di pisahkan dalam bokoa lain. Guru silat akan membakar menyan dan membaca do'a serta memohon izin kepada ruh orang tuatua silat yang sudah mendahului kita untuk anak cucunya yang ingin mempelajari pencak silat bakti, agar dalam mempelajari pencak silat tradisional bakti ini tidak terjadi hal-hal yang tidak di inginkan.

Setelah itu persyaratan ayam dibunuh dan dimakan, biasanya dilakukan dirumah guru silat dan di adakan pada malam hari, di undang para tua-tua silat, anak buah yang sudah belajar serta guru-guru silat agar mendo'akan anak buah baru ini agar apa yang mereka pelajari bermamfaat bagi diri mereka dan melekat di ingatan mereka.Persyaratan yang diberikan oleh guru silat tersebut merupakan persyaratan yang telah turun temurun dari tua silat. Setiap persyaratan memiliki makna dan tujuan tersendiri :

Menurut informasi Iben desubang memiliki makna bahwa pada saat masa Belajea, arwah nenek moyang akan hadir untuk merestui anak buah yang akan mempelajari pencak silat tradisional bakti ini, maka dari itu Iben desubang berfungsi untuk menghormati kedatangan arwah nenek moyang pada saat itu.Menurut informasi, Caci 12 ribauitu memiliki makna bahwa kita benar-benar ikhlas dan sungguh-sungguh dalam mempelajari pencak silat tradisional bakti, Caci 12 ribaunantinya diberikan kepada guru. Menurut informasipisau garpu memiliki makna silat tradisional bakti ini merupakan bagian dari adat, dan merupakan salah satu ciri budaya rejang.

Menurut informasiKain putiak 2,5 meter(Kain putih 2,5 meter) untuk silat memiliki arti agar kita tau diri, seberapapun hebatnya kita, seberapapun kayanya kita, diwaktu mati hanya akan membawa kain putih(Kafan) semua yang berasal dari Allah akan kembali kepada Allah SWT. Sedangkan kain hitam pada Mecok 
(Pencak) memiliki arti adanya yang gaib dan yang nyata, dan kita tidak perlu memusuhi yang gaib karena mereka juga merupakan ciptaan yang maha kuasa Allah SWT.

Menurut informasi Belas 12 cibuk(Beras 12 canting) memiliki arti persamaan semua manusia, beras 12 canting ini dimakan bersama dalam ruangan untuk mendoakan para anak buah baru.Menurut informasi ayam kumbang di potong memiliki makna segala bentuk yang bersifat hitam lenyab bersama matinya ayam hitam tersebut, kemudian ayam hitam dijadikan sambal guna mendo'akananak buahagar apa yang di pelajari bermakna dan bermamfaat.

Setelah semua persyaratan dipenuhi oleh calon anak buah maka sang guru mulai mengajarkan langkah pembuka dan seterunya. Pencak silat tradisional memiliki empat tingkatan belajar yaitu dasar, nukok kekea samping kiri (buka kaki kesamping kiri), nukok kekea samping kanen (buka kaki kearah samping kanan), nukok kekea samping kanen (buka kaki kea rah depan) dan nukok kekea belakang (buka kaki kea rah kebelakang). Pada tiap-tiap naik tingkatan anak buah harus mengadakan masa belajea, persyaratan yang digunakan semua dengan tingkatan dasar kecuali kain putih yang hanya sekali di berikan, dan pada tingkatan berikutnya jenis ayam yang di potong diganti. Tingkatan nukok kekea samping kiri menggunakan ayak birih kunai (Ayam kuning), tingkatan nukok kekea samping kanen menggunakan ayak utaeh (Ayam putih), tingkatan nukok kekea samping kanen menggunakana ayak ita(Ayam hitam) dan tingkatan nukok kekea belakang menggunakan mei kuning (Nasi kuning).

\section{PEMBAHASAN}

Menurut informan secara keseluruhan Pencak Silat Tradisional Bakti berkembang dengan pesat pada tahun 1965 s/d 1990, karena pada saat itu penduduk Tunggang beranggapan bahwa setiap anak laki-laki haruslah pandai pencak silat untuk menjaga diri, disamping itu seringnya terjadi pertikaian antar daerah juga menjadi faktor penduduk mengharuskan anak muda untuk mempelajari Pencak Silat Tradisional Bakti, terlebih pengalaman pahit masuknya Belanda, Inggris, Fortugis dan Jepang ke bengkulu membuat para orang tua membekali anak-anak mereka dengan ilmu bela diri Pencak Silat Tradisional Bakti ini dan masyarakat Tunggang mulai kurang mempelajari Pencak Silat Tradisional Bakti sejak tahun 1987di karenakan kemajuan zaman.

Hingga sekarang pencak silat tradisional Bakti ini perkembangannya sangat minim sekali, menurut informan hal ini dipengaruhi oleh minat generasi muda yang sangat kurang terhadap pencak silat tradisional Bakti. Menurut informan ada beberapa faktor yang menyebabkan generasi muda kurang berminat untuk mempelajari pencak silat tradisional Bakti ini yaitu masuknya olahraga beladiri baru dan moderen seperti karate, taekwondo, judo, whusu dan olah raga beladiri lainnya, selain itu informan juga berpendapat kemajuan tekhnologi juga mempengaruhi pencak silat tradisional bakti kurang diminati oleh generasi muda.

Informan juga mengatakan bahwa kinerja pelatih dahulunya sangat bagus dan baik sarana maupun prasarana sangat mendukung namun karena sejak tahun 1987anak buah yang mempelajari pencak silat tradisional Bakti ini sering patah tengah atau berenti ditengah jalan sehingga tidak muncul guru silat baru membuat perkembangan pencak silat tradisional bakti ini sangat kurang, bahkan sekarang hanya terdapat satu sasaran saja, itupun guru silatnnya sudah tua. 


\section{SIMPULAN}

Berdasarkan uraian di atas mengenai hasil penelitian yang telah dilakukan serta pembahasan yang telah di kemukakan, dapat di tarik kesimpulan sebagai berikut:Pencak silat tradisional bakti berasal dari daerah tunggang (rejang) sendiri yang dikembangkan oleh wilayo rejang (merupakan salah satu wilayah rejang), dan pencak silat berkembang pesat di Kabupaten Lebong sejak tahun 1965 s/d 1990. Asal katapencak silat baktidi angkat dari kata berbakti yang merupakanmarga tubei yang dipimping raja mawang salah satu daerah di tunggang, raja mawang memiliki 7 orang anak yaitu (1) ki geto, (2) kit tago, (3) ki ain, (4) ki jenain, (5) ki nio, (6) ki karang nio dan yang ke (7) putri serindang bulan). oleh sebab itu pencak silat trdisional yang ada di Kabupaten Lebong diberi nama Pencak silat Bakti.

Persyaratan belajar pencak silat tradisional baktiyaitu: (a) anak buah (murid) menyatakan niatnya untuk mempelajari silat tradisional bakti ini kepada guru silat, tampa adanya paksaan dari orang lain, (b) anak buah (murid) harus memenuhi persyaratan yang biasa disebut Masa Belajea, dalam masa belajea ada beberapa syarat yang harus di penuhi oleh calon anak buah dan masing-masing persyaratan tersebut memiliki makna sendiri (c) Sihaeh Sakapao (Sekapur sirih) yaitu kepercayaan bahwa arwah nenek moyang akan hadir untuk merestui anak anak buah yang akan mempelajari pencak silat tradisional bakti ini, (b) caci 12 ribau (Uang Rp. 12.000,- di sesuaikan dengan sekarang), (e) Kraih Suweah(Sebuah Keris); (f) Ahaek Utaeh Limo Itao(Kain putih 5 hasta)untuk Silaek(Silat) dan Ahaek Ita Limo Itao(Kain hitam lima hasta) untuk Menceak(Pencak) yang bermakna bahwa semua yang berasal dari Allah akan kembali kepada Allah SWT.Sedangkan kain hitam pada mecok(Pencak) memiliki arti adanya yang gaib dan yang nyata, dan kita tidak perlu memusuhi yang gaib karena mereka juga merupakan ciptaan yang maha kuasa Allah SWT; (g) belas 12 cibuk (Beras 12 canting) yang memiliki arti persamaan semua manusia, beras 12 canting ini dimakan bersama untuk mendoakan para anak buah baru dan (h) dikup monok kumbang(Seekor ayam kumbang/hitam)yang memiiki makna segala bentuk yang bersifat hitam lenyab bersama matinya ayam hitam tersebut.

\section{DAFTAR PUSTAKA}

Barlian, (2016). Metodologi Penelitian Kualitatif. Padang : Suka Bina Press

Lubis, (2016). Pencak Silat.Jakarta: PT Raja Grafindo Persada

Jafar, (2017). Tua Silat: Tunggang

Pikal, (2017). Guru Silat: Tunggang

Sugiono,(2012). Statistika Untuk Penelitian. Bandung ;CV Alfabeta 